\title{
Konsep Dasar Makna Dalam Ranah Semantik
}

\author{
Muhamad Sarifuddin \\ Email : dgreat_ngloriousone@yahoo.com
}

\begin{abstract}
Abstrak. Kajian tentang konsep dasar makna dalam ranah semantik ini merupakan kajian tentang keutuhan bahasa terletak pada hadirnya kedua lapisan itu, yakni lapisan bentuk dan lapisan makna. Keeratan hubungan ini dianalogikan sebagai dua sisi yang terdapat pada uang logam. Sisi yang satu merupakan bagian dari keutuhan sisi yang lain dan begitupun sebaliknya. Artinya salah satunya tidak mungkin dilepaskan. makna begitu penting dalam bahasa; makna itu sangat vital bagi bahasa walaupun abstrak, makna itu tetap memiliki posisi yang sentral dalam bahasa. Alasannya dengan kemampuannya dalam menyimpan makna itulah, kedudukan bahasa menjadi vital dalam kehidupan manusia. Bahasa juga adalah sarana penyampai makna dari manusia yang satu kepada manusia yang lain. Oleh sebab itu ketika bahasa dianggap sudah tidak bisa menyampaikan makna lagi, untuk apalagi ada bahasa, untuk apa diciptakan bahasa karena ternyata nilai yang penting dalam bahasa terletak pada kemampuannya dalam menyampaikan makna. Bahasa digunakan untuk mengkomunikasikan sesuatu hal apa yang terjadi dan menyatakan hubungan diluar bahasa. Salah satu cara pendekatan kajian makna adalah mencoba mengkorelasikan ekspresi-ekspresi dalam bahasa dengan aspek-aspek diluar bahasa. Hal ini dikenal dengan pendekatan ekstensional. Sesuatu diluar bahasa yang diacu oleh ekspresiekspresi tertentu disebut dengan referen (acuan). makna bersifat abstrak dan dipandang sulit untuk dideskripsikan. Dalam kurun waktu yang panjang, kajian makna masih saja diposisikan secara peripheral. Walaupun demikian, seiring dengan adanya pergeseran pandangan dari formalism menuju ke fungsionalisme, kajian makna semakin mendapat tempat yang semestinya dalam khazanah kajian linguistik. Hal ini terbukti dengan semakin populernya kajian bidang semantik dan pragmatik didalam ranah linguistik.
\end{abstract}

Kata Kunci :Semantik, Pragmatik dan Linguistik.

\section{Pendahuluan}

Dalam konteks kekinian cikal bakal perbincangan para linguis tentang bahasa sulit dilepaskan dari konsep Ferdinand de Sausure. Pernyataan ini tentu saja bukan suatu hiperbola. Faktanya sangat jelas. Sausure telah dianggap sebagai peletak dasar konsep linguistic modern yang terkenal dengan berbagai teori dikotominya tentang bahasa. Dikotomi bentuk dan makna adalah salah satu diantaranya.Dalambahasa Prancis, Sausure menyebut keduanya dengan istilah Signifiant dan Signifie. Dalam Bahasa Inggris kedua istilah itu diadaptasi menjadi Signifier dan Signified.

Sejalan dengan konsep yang disampaikan Sausure, lapisan bentuk dalam bahasa adalah bunyi bunyi yang diartikulasikan oleh alat ucap manusia. Hal itu disejajarkan dengan hakikat dari bahasa karena bahasa itu adalah bunyi. Sementara itu, lapisan makna dari bahasa adalah konsep yang ada dalam fikiran manusia yang secara otomatis diberikan ketika sebuah deret bunyi diciptakan. Prosesnya terjadi secara simultan (serta-merta). Artinya, kalau deret bunyinya ada, maknanyapun muncul. Dengan demikian keutuhan bahasa terletak pada hadirnya kedua lapisan itu, yakni lapisan bentuk dan lapisan makna. Keeratan hubungan ini dianalogikan sebagai dua sisi yang terdapat pada uang logam. Sisi yang satu merupakan bagian dari keutuhan sisi yang lain dan begitupun sebaliknya. Artinya salah satunya tidak mungkin dilepaskan.

Sebagai contoh, deret bunyi [m-a-k-a-n] mengandung konsep, yaitu "aktifitas yang yang 
Jurnal Ilmu Sosial dan Pendidikan

http://ejournal.mandalanursa.org/index.php/JISIP/index

Terakreditasi Peringkat 5 (No. SK: 85/M/KPT/2020)

biasa dilakukan mahluk hidup untuk memasukkan makana kedalam mulutnya". Sementara itu, deret bunyi [n-a-k-a-m] tidak mengandung konsep karena dalam khasanah leksikon bahasa Indonesia memang tidak dikenal adanya leksikon nakam. Dengan demikian, yang disebut bahasa tentu saja ada deret bunyi yang pertama karena ada keutuhan antara aspek bentuk atau aspekmakna. Sementara itu deret bunyi yang kedua tidak mampu menunjukkan adanya keutuhan tersebut.

Paparan diatas telah membuktikan bahwa makna begitu penting dalam bahasa; makna itu sangat vital bagi bahasa walaupun abstrak, makna itu tetap memiliki posisi yang sentral dalam bahasa. Alasannya dengan kemampuannya dalam menyimpan makna itulah, kedudukan bahasa menjadi vital dalam kehidupan manusia. Bahasa juga adalah sarana penyampai makna dari manusia yang satu kepada manusia yang lain. Oleh sebab itu ketika bahasa dianggap sudah tidak bisa menyampaikan makna lagi, untuk apalagi ada bahasa, untuk apa diciptakan bahasa karena ternyata nilai yang penting dalam bahasa terletak pada kemampuannya dalam menyampaikan makna

Karena begitu pentingnya makna dalam bahasa, dalam tradisi linguistik pun muncul cabang ilmu yang secara khusus yang bertugas untuk mengkaji makna, yaitu bidang semantik dan pragmatik. Semantik diposisikan sebagai cabang linguistic yang mengkaji makna secara intralingual, sedangkan pragmatik diposisikan sebagai cabang linguistic yang mengkaji makna secara ektralingul. Mengapa disebut demikian? Alasannya semantic hanya melibatkan aspek bentuk dan aspekmakna yang ada didalam lingkungan bahasa ketika mengkaji makna bahasa. Sementara itu pragmatik selain melibatkan aspek bentuk dan aspek makna juga melibatkan aspek konteks yang berada diluar lingkungan bahasa ketika mengkaji makna bahasa. Dengan demikian dalam makalah ini selanjutnya akan dibahas sebagai konsep dasar
Vol. 5. No. 2 Maret 2021

p-ISSN: 2598-9944 e-ISSN: 2656-6753

yang berkaitan dengan makna. Konsep tersebut adalah Meaning, sense, denotation, reference, proposition, dan intention. Makna atau pengertian dari konsep konsep tersebut merupakan akan dipaparkan pada bagian pembahasan berikut.

\section{Pembahasan}

\section{Meaning, Sense dan Denotation}

Persoalan makna sampai sekarang masih membingungkan untuk di definisikan. Kalau kita bertanya tentang "apa makna itu?", tentunya sulit bagi kita untuk menjelaskannya. Seandainya kita jelaskan dengan kata kata, maka akan terjadi tarik ulur yang tidak akan ada ujungnya. Semisal, kita sering mendengar sebuah ujaran "what do you mean?" (apa yang kamu maksudkan),"what is the meaning of sematics"(apa arti dari semantik) atau "what is the definition of semantics?"(apakah definisi dari semantic?). Dari contoh tersebut kita sulit untuk membedakan makna, arti, maksud dan informasi. Bahkan lazimnya orang akan menganggap semua itu adalah makna.

Seandainya semantik adalah istilah yang digunakan untuk bidang linguistic yang mempelajari hubungan antara tanda-tanda linguistic denngan hal-hal yang ditandainya (Chaer: 1995), tentunya harus dimengerti dan difahami makna dari istilah, bidang, linguistik, hubungan dan tanda. Selama kita tidak mengerti makna kata yang tercetak miring diatas, tentunya kita tidak akan faham dengan makna semantic tersebut. Dengan demikian, makna merupakan persoalan bahasa yang memiliki hubungan keterikatan dengan segala segi kehidupan manusia yang sangat kompleks dan luas.

\subsection{Makna dan Arti}

Pengertian makna (sense) dalam hal ini dibedakan dengan arti (meaning). Makna adalah pertautan yang ada diantara unsurunsur bahasa itu sendiri. Makna menyangkut intra bahasa. Sementara itu, arti dalam hal ini hanya menyangkut makna leksikal dari kata- 
kata itu sendiri yang cenderung terdapat dalam bahasa kamus sebagai leksem.

Untuk lebih memahamiapa itu makna konsep dasarnya tentu paling mudah kita kembalikan kepada bapak linguistik modern kita, yaitu Ferdinand de Sausure, dengan apa yang disebut sistem tanda (sign). Mengapa demikian?, konsep ini sejalan dengan apa yang telah disebutkan diatas bahwa semantik adalah ilmu yang mempelajari sistem tanda. Sausure berpendapat bahwa setiap tanda linguistik terdiri atas dua unsure, yaitu signified 'yang diartikan' dan signifier 'yanng mengartikan'. Secara singkat dijelaskan bahwa signified adalah konsep atau makna dari suatu tanda dan signifier adalah bunyi yang terbentuk dari fonemfonem bahasa yang bersangkutan. Artinya, kalau kita ibaratkan signified dan signifier seperti dua sisi yang terdapat dalam satu keeping uang logam, sisi yang satu dengan sisi yang lain menyatu dan tidak bias dipisahkan. Tentunya kita tidak akan membeli sebuah pakaian dalam ditoko dengan uang yang bergambar sesisi saja karena kita ankan ditangkap polisis karena kita akan dianggap pengedar uang palsu.

\subsection{Makna dan Informasi}

Lyon dalam Djajasudarma (1999) menyebutkan bahwa mengkaji atau memberikan makna sesuatu kata ialah memahami kajian kata tersebut yang berkenaan dengan hubungan-hubungan makna yang membuat kata tersebut berbeda dengan kata-kata yang lain. Oleh sebab itu, apabila bentuk (maksudnya bentuk kata atau leksem) berbeda, makna pun akan berbeda, meski perbedaan tersebut sangat tipis. Meminjam istilah Chaer (1995), makna adalah gejala dalam ujaran (utteranceinternal phenomenon), sedangkan informasi gejala luar ujaran (utterance-external phenomenon).

Kita seringnya tidak begitu memperhatikan perbedaan antara makna dan informasi dan lebih seringnya juga menyamakan keduanya. Suatu contoh kata ayah dan bapak, sekilas dua bentuk kata tersebut memberikan informasi yang sama karena keduanya sama-sama mengacu kepada orang tua laki-laki. Namun, keduanya memiliki makna yang berbeda karna bentuknya juga lain. Juga dalam contoh berikut, "Nano meremas jari Nani semalam" dan "Semalam jemari Nani diremas oleh Nano”. Kalimat ini seakan memiliki makna yang sama karena kedua kalimat tersebut memberikan informasi yang sama kepada kita. Namun, karena bentuknya berbeda, maknanya pun secara semantik berbeda.

\subsection{Makna dan Maksud}

Selain informasi sebagai suatu gejala luar, ujaran, ada juga gejala luar ujaran yang lain yang disebut dengan maksud. Perbedaan antara informasi dan maksud terletak pada sudut yang dibicarakan. Informasi dilihat dari segi objek atau apa yang dibicarakan, sedangkan maksud melihat dari segi subjek atau pengujar atau lebih tepatnya orang yang berbicara. Artinya, ketika si pengujar mengujarkan sesuatu yang dimaksudkan, sesuatu yang dimaksudkan itu tidak sama dengan makna secara lahiriahnya. Sebagai contoh, saat diterminal Mandalika Sweta Mataram, kita mendengarkan seorang kondektur bus berteriak-riak "Praya, Praya..!". Selain itu, disebelah kita ada juga pedagang asongan yang menawarkan dengannya, “Jeruk,jeruk...!" atau "jeruknya mas, besar-besar lho...!, bulat lagi...." Dengan jelas sekali, kita dapat mengetahui makna yang dimaksud oleh pembicara yang keduanya yang bermaksud menawarkan.

\subsection{Makna dan Referen}

Bentuk kebahasaan memiliki hubungan dengan konsep dalam fikiran manusia yang disebut dengan makna (sense). Konsep ini lazimnya berhubungan dengan sesuatu hal yang ada diluar bahasa yang disebut referen (referent). Makna tidak selalu memiliki referen sehingga makna lebih 
bersifat umum atau tidak tentu, sementara referen lebih bersifat khusus atau tertentu. Apabila seseorang mengatakan computer, kata tersebut tidak menunjukkan computer tertentu, tetapi semua yang dapat disebut komputer.

Referen adalah sesuatu yang diacu oleh konsep bentuk bahasa yang bersangkutan. Bentuk bahasa berhubungan langsung dengan konsep fikiran (makna); makna berhubungan langsung dengan referen. Namun bentuk kebahasaan berhubungan tidak langsung dengan referen. Hubungan ini disebut dengan referensial. Hubungan tersebut digambarkan melalui apa yang disebut segi tiga semiotic (semiotic triangle) oleh Ogden dan Richards.

Thought of reference

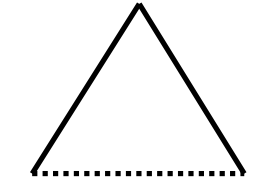

Symbol

referen

\section{Denotation}

Makna konseptual disebut juga makna denotative atau kognitif yang dianggap faktor sentral dalam komunikasi bahasa. Menurut pemikiran Leech (2003) hal tersebut dapat ditunjukkan sebagai yang terpadu bagi fungsi esensial atas suatu bahasa, tidak seperti tipetipe makna yang lain (tidak berarti bahwa makna konseptual selalu merupakan unsur terpenting didalam suatu komunikasi bahasa).

Chaer (1995:59) mengungkapkan bahwa jenis makna atau tipe makna dapat dibedakan berdasarkan beberapa criteria dan sudut pandang. Berdasarkan jenis semantiknya dapat dibedakan antara makna leksikal dan makna grammatikal; berdasarkan ada tidaknya referen pada sebuah kata atau leksem dapat di bedakan adanya makna referensial dan makna nonreferensial; berdasarkan ada tidaknya nilai rasa pada sebuah kata atau leksem dapat dibedakan adanya makna denotatif dan makna konotatif.

Jurnal Ilmu Sosial dan Pendidikan

\section{Proposition}

Menurut Kridalaksana (1984) dalam Kamus Linguistik, Proposition (proposisi) adalah (1) konfigurasi makna yang menjelaskan isi komunikasi dari pembicaraan; terjadi dari predicator yang berkaitan dengan satu argument atau lebih;

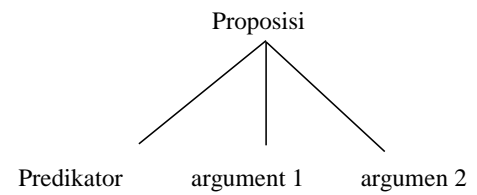

Misal : Adik makan nasi

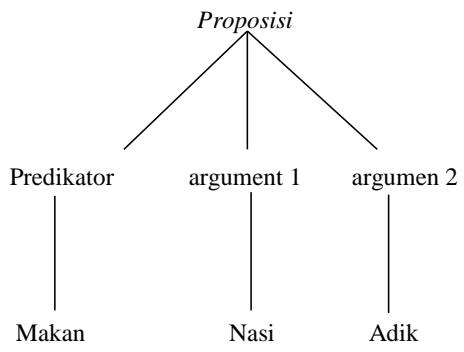

apa yang dapat dipercaya, disangsikan, disangkal atau dibuktikan benar atau salah, sebagaimana terkandung dalam klausa; makna klausa.

\section{Sense, Denotation dan Reference: Intensi dan Ekstensi}

Bahasa digunakan untuk mengkomunikasikan sesuatu hal apa yang terjadi dan menyatakan hubungan diluar bahasa. Salah satu cara pendekatan kajian makna adalah mencoba mengkorelasikan ekspresi-ekspresi dalam bahasa dengan aspekaspek diluar bahasa. Hal ini dikenal dengan pendekatan ekstensional. Sesuatu diluar bahasa yang diacu oleh ekspresi-ekspresi tertentu disebut dengan referen (acuan). Ketika mengatakan "Kucing itu lapar", sebenarnya saya sedang mengacu terhadap kucing tertentu dan kucing itu merupakan acuan dari ekspresi kucing. Keseluruhan ujaran tersebut menghubungkan ungkapan tertentu terhadap kucing.

Sesuai dengan pendapat Lyon, kelas kucingm erupakan denotasi dari kata kucing.Oleh karena itu, dalam kata kucing itu 
lapar, kata Kucing mendenotasikan kelas kucing. Akan tetapi, kata kucing merujuk pada kucing tertentu.

Alternatif dari pendekatan ekstensi adalah pendekatan intense. Sebagai contoh, kata kucing, mengapa kita menggunakan kata kucing ini untuk merujuk kucing daripada mengatakan waung, trenggiling atau kebo?. Jawabannya adalah bahwa kata itu diasosiasikan dengan suaturepresntasi mental. Artinya, hal ini dapat digunakan untuk mengacu. Sementara itu, kata waung atau jenis binatang lain dan kata penunjuk binatang yang lai itu tidak dapat dideskripsikan dengan tepat ketika diasosiasikan dengan kata [k-u-c-i-n-g]. Representasi ini disebut dengan sense (makna kata). Kita dapat mengasumsikan bahwa fungsi utama dari ekspresi linguistic adalah untuk memobilisasi konsep, sedangkan konsep adalah konstituen utama dari sense,dan sense atau makna tidak dibatasi oleh reference. Dalam hal ini perlu dicatat bahwa Lyon memahami sense dengan cara yang berbeda; sense adalah suatu hubungan antara kata dan kata-kata yang lain dalam sebuah bahasa. Sebagai contohnya, makna dari kucing akan dikonstitusikan oleh hubungan-hubungannya dengan kata lain seperti anjing (kucing sebenarnya bukanlah anjing), binatang (kucing adalah binatang), meong (kucing meong itu kedengarannya wajar atau normal, tetapi kalao anjing meong itu tidak wajar).

\section{KESIMPULAN}

Sepertinya para linguis sudah tidak lagi berdebat bahwa makna adalah aspek sentral dalam bahasa. Namun, karna makna bersifat abstrak dan dipandang sulit untuk dideskripsikan. Dalam kurun waktu yang panjang, kajian makna masih saja diposisikan secara peripheral. Walaupun demikian, seiring dengan adanya pergeseran pandangan dari formalism menuju ke fungsionalisme, kajian makna semakin mendapat tempat yang semestinya dalam khazanah kajian linguistik. Hal ini terbukti dengan semakin populernya bidang semantic dan pragmatik didalam linguistik.

Sebagaimana telah diuraikan dimuka, tulisan singkat ini masih bersifat pengenalan teoritis terhadap sejumlah konsep makna yang lazim digunakan dalam kajian semantik dan pragmatik (lebih khusus dalam semantik). Artinya, konsep meaning,sense, denotation, reference, proposition dan intention hanya dibahas sekedarnya sebagai bekal awal untuk melangkah pada kajian makna yang sesungguhnya. Adapun pengenalan dan penjelasan lebih jauh tentang berbagaijenis makna akan disampaikan oleh kelompok berikutnya.

\section{Daftar Pustaka}

Chaer, abdul 1995. Pengantar Semantik Bahasa Indonesia. Jakarta: Rineka Cipta

Cruse, D.A. 2000. Meaning in Language. An Introduction to Semantics and Pragmatics. New York: Oxford University Press.

Djajasudarma, T. Fatimah. 1999a. Semantik1: Pengantar ke Arah Ilmu Makna. Bandung: Refika.

. 1999b. Semantik 2:Pemahaman Ilmu Makna. Bandung: Refika.

Kridalaksana, Harimurti. 1984. Kamus Linguistik. Jakarta: Gramedia.

Leech, Geoffrey.2003.Semantik, edisi terjemahan oleh Paina Partana. Yogyakarta: Pustaka Pelajar.

Wijana, I Dewa Putu dan MuhammadRohmadi. 2008. Semantik,Teori dan Analisis. Yogyakarta: Yunia Pustaka. 